\title{
Plant establishment on angle of repose mine waste dumps
}

\author{
KATRINA J. LEAVITT, GEORGE C.J. FERNANDEZ, AND ROBERT S. NOWAK
}

Authors are rangeland management specialist, BLM Carson Field Office, 5665 Morgan Mill Road,Carson City, Nev. 89701; associate professor, Applied Economics and Statistics Department/MS 204, University of Nevada-Reno, Reno, Nev. 89557; and professor, Department of Enviromnental \& Resource Sciences/MS 370, University of Nevada-Reno, Reno, Nev. 89557. At the time of the research, the senior author was a minerals management intern, HumboldtToiyabe National Forest, Mountain City, Nev. Send requests for reprints to RSN.

\section{Abstract}

Angle of repose slopes associated with mine waste dumps are difficult to revegetate due to steep slope angle, poor soil properties, and potential for extensive soil erosion. We examined the extent that seed movement, seedling establishment, soil characteristics, nutrient availability, and water availability were responsible for limiting plant establishment or survival on steep (average slope $\sim \mathbf{8 0 \%}$ ), south-facing angle of repose slopes at a gold mine north of Elko, Nev. Four treatments were established: 1) unaltered mine waste soil; 2) mine waste soil with fertilizer; 3) mine waste soil draped with at least $0.3 \mathrm{~m}$ of a fine-textured coversoil; and 4) treatments 2 and 3 combined. All treatments had study plots that received either broadcast seeds or containerized transplants. Seedlings from broadcast seeds only emerged on plots that were coversoiled, but transplants survived in all treatments. Thus, coversoiling was necessary at this site for seedling germination and establishment, but survival of transplants in unaltered mine waste soil indicated that nutrient availability, soil-root contact, and water availability were sufficient for plant survival. In addition, long distance transport of seeds down stable, angle of repose slopes was not detected during the first growing season after seeding, indicating that the lack of seedlings on angle of repose slopes was not due to movement of seeds downslope. However, coversoiling resulted in unstable slope surfaces; both erosion and soil mass wastage were observed on coversoiled treatments. Thus, although coversoiling increased establishment and survival of plants on angle of repose slopes, slope stabilization is necessary to ensure the success of revegetation efforts and to prevent the coversoil from eroding and moving downslope.

Key Words: seed fate and transport; seedling transplants; nutrient and water availability; growth medium; mine reclamation; revegetation

Our ability to return surface-mined areas to productive use has increased greatly over the last 3 decades as our knowledge of successful techniques and ecological processes has grown. Although

This project was funded in part by Independence Mining Company Inc., the USDA Forest Service, and the Nevada Agricultural Experiment Station; RSN also gratefully acknowledges sabbatical leave support from the University of Nevada Reno. We appreciate reviews of earlier drafts by J. Chambers, R. Tausch, D. Taylor, our first floor Fleischmann Ag. colleagucs, and 2 anonymous reviewers. We are very grateful to D. Leavitt for extensive lab and field assistance, J. Collard for logistical support and mine operations coordination, G. Hinshaw for the Spanish abstract translation, and C. Nowak for transplant culture and seed bank analysis.

Manuscript accepted 8 May 1999.

\section{Resumen}

El ángulo de reposo de las laderas asociadas con el depósito de deshecho de minas hace dificil la revegetación debido a lo pronunciado del ángulo de la ladera, las propiedades pobres del suelo, y su potencial extensivo para la erosión. Nosotros examinamos hasta qué punto el movimiento de la semilla, el establecimiento de la plántula, las características del suelo, la disponibilidad de los nutrientes y la disponibilidad de agua fueron responsables de limitar el establecimiento o sobrevivencia de las plantas en laderas con ángulo de reposo pronunciado (promedio de inclinación de $\sim 80 \%$ ) con exposición sur en una mina de oro al norte de Elko, Nev. Cuatro tratamientos fueron establecidos: 1) suelo de deshecho de mina inalterado; 2) suelo de deshecho de mina con fertilizante; 3 ) suelo de deshecho de mina con una cubierta de al menos $0.3 \mathrm{~m}$ de suelo de textura fina; y 4) los tratamientos 2 y 3 combinados. En todos los tratamientos se establecieron parcelas de estudio donde se dispersaron semillas o se trasplantó en recipientes cónicos. Las plántulas de las semillas dispersadas emergieron únicamente en las parcelas que fueron cubiertas con suelo, pero los transplantes sobrevivieron en todos los tratamientos. Por lo tanto, el cubir el suelo en este sitio fué necesaria para la germinación y el establecimiento de las plántulas, pero la sobrevivencia de los transplantes en el suelo de deshecho de mina sin alterar indicó que la disponibilidad de nutrientes, el contacto suelo-raiz, y la disponibilidad de agua fueron suficientes para la sobrevivencia de las plantas. En adición, no se detectó transporte a larga distancia, ladera abajo, de las semillas en ángulos de reposo de laderas estables durante la primera estación de crecimiento posterior al sembrado, indicando que la falta de plántulas sobre el ángulo de reposo de las laderas no se debió al movimiento de semillas ladera abajo. Sin embargo, cubrir el suelo dió por resultado superficies de laderas inestables; ambos erosión y desgaste de suelo en masa fueron observados en los tratamientos de cobertura de suelo. Por lo tanto, aunque cubrir el suelo incrementó considerablemente el establecimiento y la sobrevivencia de las plantas sobre el angulo de reposo de las laderas, es necesario estabilizar las laderas para asegurar el éxito en los esfuerzos de revegetación y para prevenir la erosion y el movimiento ladera abajo de la cubierta del suelo.

site specific characteristics need to be carefully assessed, recent reclamation handbooks and manuals (e.g. Ferris et al. 1997, Harris et al. 1996, Munshower 1994) provide sound guidance on techniques that work in most cases. Typically, mine reclamation includes recontouring to reduce erosion, topsoilng to provide a plant growth medium, seedbed preparation to maximize germination and plant establishment, soil amendments (e.g. fertilizer or 
mulch) to enhance plant growth, and seeding or transplanting suitable plant species. Although each step of the process is needed to ensure success, the importance of topsoiling cannot be overemphasized (DePuit and Redente 1988). In fact, many reclamation laws require topsoiling, either with true topsoil (i.e. soil taken from near the surface of vegetated areas) or with a coversoil (i.e. material that exhibits good plant-growth supporting characteristics) (Munshower 1994).

Unfortunately, not all sites are amenable to typical reclamation approaches. For example, topsoiling steep (>50\% slope), angle of repose slopes in mine waste dumps is especially problematic because of the high erosion potential. Angle of repose slopes are formed when waste rock is dumped and left to form its own slope due to gravity. Although once a common practice throughout historic mining districts in western North America, few angle of repose dumps are now constructed. However, steep topography and limited space sometimes require angle of repose slopes (Young and Ross 1993). The existence of old barren mine dumps indicates the difficulty of establishing vegetation on these slopes. Field trials have demonstrated some successful revegetation practices (e.g. Golder 1994), but the mechanisms that explain these limited successes are unclear. Thus, studies that better identify factors that limit plant establishment on angle of repose slopes are needed.

Occasionally, angle of repose dumps are not completely barren. Observations of naturally vegetated mine slopes have shown higher plant cover and species richness at the bases of slopes in comparison with upper and mid slopes (Russell 1985). Four mechanisms may explain the observed differential pattern of vegetation establishment. The first mechanism is seed transport (Archibold 1980). Once seeds reach the soil surface, they may remain trapped where they land, move horizontally over the soil surface, or move vertically through the soil column (Chambers and MacMahon 1994). If seeds are transported down slope by wind, water, or gravity, then a seed gradient should exist on the slope with few seeds at the top of the slope and many at the bottom. In addition, coarse-textured soils capture a greater range of seed sizes in comparison with fine-textured soils, but more seeds move vertically through the soil column (Chambers 1995). If seeds move too deep into the soil, they may not germinate or may not have sufficient resources to grow to the soil surface. A second mechanism is the movement of fine soil particles to the base of the slope (Molyneux 1962). Soil texture influences seed germination and plant growth by its direct effect on soil aeration, water infiltration, water retention, cation exchange capacity and erodibility (Munshower 1994). The accumulation of fine soil particles near the base of the slope may create sites that are more favorable for seed germination and seedling establishment because fine materials often facilitate seed-soil and root-soil contact. A third mechanism is nutrient transport down slope. The leaching of water-soluble nutrients from the top of the angle of repose face may result in a gradient of nutrient availability, from fewer available nutrients at the top of the face to higher amounts at the base. Finally, water accumulation down slope is a fourth possible mechanism. Water runoff increases with slope steepness and length (Gray and Leiser 1982). The steepness of angle of repose slopes increases the runoff velocity whereas terraced benches decrease runoff. Snow may also preferentially accumulate near the base of the slope. These factors likely interact; for example, fine soil materials that accumulate down slope likely increase nutrient availability and water holding capacity.

The overall goal of this study was to determine the relative importance of these 4 mechanisms for revegetation of angle of repose slopes. To determine if seed movement was the critical factor influencing plant establishemt, measurements of seed bank at different locations along the slope face and of differentially-dyed seeds placed at specific locations along the slope face were made on unaltered mine waste and coversoiled plots. If gradients in seed density occur and if seeds dyed a specific color are found outside the area that they were placed, then long distance transport of seed likely would be an important influence on revegetation. If seed germination and seedling survival are greater on finetextured coversoil but survival of transplants are similar on mine waste and coversoil, then the more favorable sites for seed germination and plant establishment provided by fine-textured coversoil likely would limit revegetation. Similarly, if survival of transplants is greater on fertilized plots but seedling density is similar among plots, then nutrient deficiencies likely would limit plant establishment. Finally, we assessed the extent that water limited revegetation of angle of repose slopes by measurements of plant water potential.

\section{Materials and Methods}

\section{Experimental Design}

The overall experimental design was a split-strip-split plot design with 2 replicates. Plots were established on 2 replicate waste rock dumps: North Generator (41 $\left.{ }^{\circ} 24^{\prime} 19^{\prime \prime N} 115^{\circ} 59^{\prime} 02^{\prime \prime} \mathrm{W}, 2,286 \mathrm{~m}\right)$ and Burns Basin (41 ${ }^{\circ} 20^{\prime} 06^{\prime \prime} \mathrm{N} 116^{\circ} 00^{\prime} 52^{\prime \prime} \mathrm{W}$, 2,195 m) dumps at the Jerritt Canyon Mine located 64 kilometers north of Elko, Nev. Slopes used in the experiments had south aspects and steepness that averaged $80 \%$. At each dump, 2 sets of plots, each consisting of 4 main plots, were located along the face of the dump. A random draw without replacement method was used to assign 1 of 4 treatments to each main plot within a set of plots. Main plots were oriented along the face of each dump, and 2 study plots were then placed on each main plot (Fig. 1 ). The upper plot was located near the top of the slope and the lower plot was $5 \mathrm{~m}$ below the bottom of the upper plot. Each study plot was $10 \times 10 \mathrm{~m}$ a $2.5 \mathrm{~m}$ buffer area around the study plot.

The 4 main plot treatments consisted of untreated mine waste, coversoil, fertilizer, and fertilizer plus coversoil. The coversoil treatment was a layer of at least $0.30 \mathrm{~m}$ of fine-textured pit material. North Generator Dump plots were draped with a clay loam coversoil from the Winters Creek Pit, whereas Burns Basin Dump plots were draped with silt loam coversoil from the Burns Basin Pit. To apply the coversoil. the coversoil was end dumped by haul trucks at the top of each of the respective plots. The coversoil piles were then pushed over the edge of the dump face with bulldozers, and the coversoil slid down to cover the mine waste. Although this method was the only practical way to place the coversoil over a large area on steep slopes, this method resulted in portions of the plots having up to $1.5 \mathrm{~m}$ of coversoil. We did not systematically measure variation in coversoil thickness because of worker safety and slope stability concerns. Although variation in coversoil thickness may eventually influence plant productivity (DePuit and Redente 1988) and diversity (Munshower 1994), we believe that variation in coversoil thickness did not seriously confound our studies, especially studies of seed movement and initial plant establishment. The fertilizer treatment was $45 \mathrm{~kg} \mathrm{ha}^{-1}$ each of $\mathrm{N}, \mathrm{P}$, and $\mathrm{K}$. To apply the fertilizer, 300 bulk kg ha-1 of 15:15:15 Plant Food (Simplot ${ }^{\mathrm{TM}}$, Lanthrop, Calif.) was hand broadcast on 5-7 February 1995 on the respective plots and their buffer areas. 


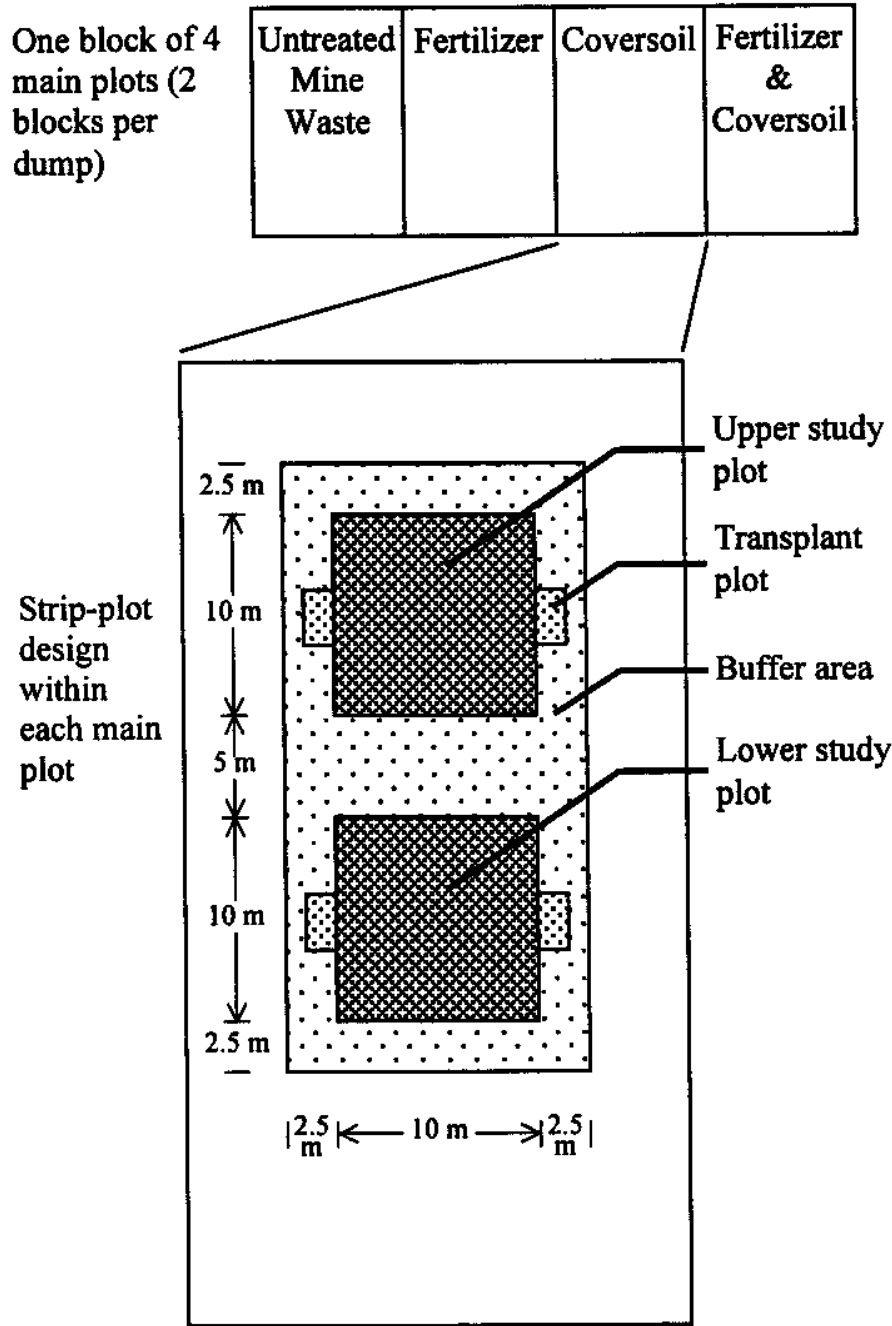

Fig. 1. Schematic representation of the split-strip portion of the experimental design; each block had 4 main plots that were split into 2 study plots. Not shown are the 2 waste rock dumps, with 2 blocks of main plots at each dump.

\section{Seeding and Planting Techniques}

Seeding viable seeds - Upper study plots, lower study plots, and the buffer area around study plots were seeded by hand broadcasting at a total rate of 323 pure live seeds (PLS) $\mathrm{rn}^{-2}$ (30 PLS $\mathrm{ft}^{-2}$ ) on 5-7 February 1995. The seed mix contained equal numbers of PLS for each of 10 species: 1) Elymus hispidus (Opiz) Melderis (intermediate wheatgrass; previously known as Agropyron intermedium); 2) Bromus inermis Leyss. (smooth bromegrass); 3) Elymus elymoides (Raf.) Swezey (bottlebrush squirreltail; previously known as Sitanion hystrix); 4) Linum lewisii Pursh (Lewis' blue flax); 5) Penstemon palmeri A. Gray (Palmer's penstemon); 6) Sanguisorba minor L. (small burnet); 7) Artemisia tridentata Nutt. subspecies vaseyana (mountain big sagebrush); 8) Atriplex canescens (Pursh) Nutt. (fourwing saltbush); 9) Chryso thamnus nauseosus (Pall. In Pursh) Britton in Britton and A. Br. (rubber rabbitbrush); and 10) Purshia tridentata (Pursh) DC. (antelope bitterbrush). Seeds were purchased from Granite Seed Company (Lehi, Utah). Seeds for each species were from the same seed lot, except for Sanguisorba minor, Linum lewisii, and Elymus hispidus. For these 3 species with different seed lots, the 2 lots for an individual species were mixed together to ensure a uniform seed mix throughout the experiment.

Sterilized dyed seeds-Sterilized, dyed seeds were used to track seed movement and changes in seed density through time. Because we did not expect the fertilizer treatment to influence movement or density of dyed seeds, only untreated mine waste and coversoiled plots were used for this portion of the study. Seeds were soaked in concentrated dye for 24 hours.
Seeds for the upper plots were dyed neon pink and seeds for the lower plots were dyed neon green. The dye solution was drained off, then seeds were baked at $177^{\circ} \mathrm{C}$ until dry. Baking also sterilized the seeds and eliminated the possibility of dyed seeds germinating. Although we planned to use all 10 species used in the revegetation seeding, 2 species were not used; Penstemon palmeri seeds did not absorb the dye, and exposure to water activated the mucilaginous coat of Linum lewisii. Dyed seeds were prepared to attain 32 seeds $\mathrm{m}^{-2}$ for each of the 8 species for individual sample plots, and then combined with pure live seed mixes for each upper and lower study plot. Dyed seeds were hand broadcast with viable seeds on 5-7 February 1995.

Transplants-To determine if plants were capable of growth on angle of repose slopes. 6-month-old seedlings of Bromus inermis, Elymus elymoides, Penstemon palmeri, Sanguisorba minor, Chrysothamnus nau seosus, and Purshia tridentata plants were transplanted into the buffer areas. All 6 species were grown from the same seed lots used for the seeding portion of the experiment. Two species, Penstemon palmeri and Purshia tridentata, required a stratification treatment before germination. Purshia tridentata was soaked in water for 24 hours (Meyer and Monsen 1989). Then both Purshia tridentata and Penstemon palmeri seeds were sealed in individual tea bags, buried in moist sterilized sand, and placed in a $3{ }^{\circ} \mathrm{C}$ walk-in cooler for 7 weeks. Cold-stratified seeds from these 2 species as well as seeds from the other 4 species were germinated at room temperature on moist filter paper in petri dishes, then planted into $164 \mathrm{ml}$ Cone-tainers ${ }^{\mathrm{TM}}$ (Stuewe and Sons, Inc., Corvallis, Ore.) that were filled with a 65:10:25 mixture of topsoil, humus, and coarse sand.

Seedlings were cultured in a glasshouse for 4 months, during which time they were supplied with ample amounts of water and NPK fertilizer. Day length was also increased to 18 hours day ${ }^{-1}$ using $1 \mathrm{~kW}$ metal halide lamps (Ruud Lighting, Racine, Virg.). Starting in the fifth month, plants were hardened by gradually decreasing watering and fertilization frequencies and by decreasing greenhouse temperatures. During the second week of the fifth month, transplants were placed outside under a shade shelter and covered at night with a tarp to prevent frost damage. After 1 week outside, plants were moved to full sunlight but were still covered with a tarp at night. The plants were transported to the mine site on 28 April 
1995, when they were approximately 6 months old. Over the next 10 days, containerized stock were planted into transplant plots within the buffer area on both sides of the upper and lower study plots (Fig. 1). Each transplant plot contained 60 individual plants. Ten individuals of each species were planted in a vertical row at $0.3 \mathrm{~m}$ apart; horizontal placement of the 6 species rows within each transplant plot was randomly assigned. "Dibbles" were used to make holes in the soil for the plants. Plants were gently removed from the Cone-tainers ${ }^{\mathrm{TM}}$, placed into the dibbleholes, and soil was gently placed around the individual plants.

\section{Vegetation Sampling}

Seedling establishment-Seedling density in each study plot was measured once a month from June through September 1995 and from May through September 1996. We counted the number of seedlings in 23 sample plots by systematically placing $0.09 \mathrm{~m}^{2}$ plots across a study plot.

Transplant survival-Survival of transplants was evaluated once a month from June to September 1995, from May to September 1996. and once during May 1998. A plant was considered alive if it still had green leaves.

Plant water potential-Plant water potential measurements were collected at predawn and midday once every month from June to September 1995. Because it was unsafe to traverse slopes before first light, predawn measurements were collected after sunrise but before plots received direct sunlight. Water potential was measured on transplants of 3 species: Elymus elymoides, Penstemon palmeri, and Chrysothamnus nauseosus. These species were selected because they were representative grass, forb and shrub species plus they had plant characteristics that facilitated measurement of water potential. One transplant plot associated with each study plot (right or left) was randomly selected (Fig. 1). Within the sampled transplant plot, 3 independent water potential samples were collected from each of the 3 species sampled. A pressure chamber was used to determine leaf water potential (Waring and Cleary 1967, Holbrook et al. 1995) for Elymus elymoides and Penstemon palmeri and stem water potential for Chryso thamnus nauseosus. Leaves and stems were enclosed by plastic bags before excision to minimize measurement errors (Turner and Long 1980).

Plant nitrogen content and biomass - In order to measure plant nitrogen pools, samples were collected 27-30 July 1995. One transplant was harvested per study plot for the same species used for water potential measurements: Elymus elymoides, Pen stemon palmeri, and Chrysothamnus nau seosus. Transplants were cut at ground level, placed in paper sacks, and air-dried. Once dry, samples were separated into stem, leaf, and reproductive components.

Prior to analysis of total nitrogen content, plant tissues were dried in a $60^{\circ} \mathrm{C}$ oven for 24 hours. Samples were weighed, then coarsely ground with a Wiley mill and finely ground with a MSD model dental amalgamator (Crescent Dental Manufacturing Company). A portion of the sample was then analyzed for percent total nitrogen with a Perkin-Elmer model $2400 \mathrm{CHN}$ analyzer. Total aboveground plant nitrogen pools were calculated by multiplying the dry weight of each biomass component (stem. leaf, and reproduction) by its percent nitrogen content, then summing the products for each individual plant.

Plant canopy volume was measured on 24 May 1998 from 2 transplants per study plot for the same species used for water potential and plant nitrogen measurements. Maximum canopy width and the width perpendicular to the maximum were measured for Chrysothamnus nauseosus and Penstemon palmeri. Maximum basal width and the basal width perpendicular to the maximum were measured for Elymus elymoides. Maximum canopy height exclusive of seed stalks was measured from ground level. The mathematical formula for an ellipsoid was then used to calculate canopy volume.

\section{Seed Bank and Soil Sampling}

Seed bank-Soil cores to assess the seed bank were collected from unaltered mine waste and coversoil treatments. Samples were collected on 3 February 1995 (2 days prior to the seeding treatment), on 18 June 1995 (4.5 months after seeding), and on 4 November 1995 (9 months after seeding). Prior to sampling, each upper and lower study plot was divided into nine, $3.33 \mathrm{~m}^{2}$ sections and 4 of the 9 sections were randomly selected for sampling. In addition, the $5 \times 10 \mathrm{~m}$ area between the study plots and an area of equal size below the lower study plots were each divided into 4 equal sections. One sample was collected from each of the 4 sections. A $10-\mathrm{cm}$ diameter by 5 -cm deep soil core ( 0.5 liter) was collected from all of the selected sections. Areas with stable, finer textured soils were preferentially sampled (as opposed to rocky areas or areas that were within erosion rills). These areas were chosen because they represent areas that are most conducive to seed germination and plant establishment, but note that they are not necessarily representative of the entire plot. After each soil core was collected, a pin flag was used to mark the sampled area to prevent repetitive sampling of the same area, but the holes were not backfilled.

Soil cores were air-dried and processed through a series of 4 soil sieves, which broke up dirt clods and allowed rocks to be retrieved and discarded. Seeds and other organic matter were then retrieved from the sieved soil using a water flotation method (Keeley 1978). Once dry, samples were examined under a microscope, and seeds were collected and identified. Seed recovery was calculated as the number of seeds extracted from the 0.5 liter soil cores divided by the total number of seeds expected given the cross sectional area of the soil core and the initial seeding rate; values are expressed as a percentage of the expected number of seeds.

Soil nutrient status - Soil samples were collected twice during the experiment to determine available soil nutrients. The first samples were collected 14-15 October 1994 prior to fertilization and seeding. The purpose of the initial soil samples was to determine if heavy metals within the soil might inhibit or prevent plant growth and to determine a fertilization rate. Two sets of soil samples were collected: 1 set for general nutrient status and the other set for the heavy metals arsenic and mercury. For general nutrient status, four, 0.5 liter soil cores were collected in a manner similar to that for seed bank analysis, then composited. Soil samples were allowed to air dry and then sent to Utah State University Analytical Laboratories for standardized soil analyses ( $\mathrm{pH}$, electrical conductivity, phosphorus (Olson method), potassium, texture, lime, total nitrogen, nitrate, organic carbon, particle size, and percent coarse figments). To reduce cost, only 16 of the 32 composited samples were analyzed: 1 composited sample from either the upper or lower study plot within each main plot was randomly selected for analysis. Eight of the 16 samples were randomly selected and also tested for cation exchange capacity.

For heavy metal analysis one, 0.5 liter soil core was collected from 2 slope locations in each main plot. The upper and lower study plot samples were then composited into 1 sample for each main plot. The samples were composited again by main plot treatment type. A total of eight, 2-liter soil samples (4 per dump) were sent 
to Chemex labs (Sparks, Nev.) and analyzed for arsenic and mercury. Because we had no indication of soil properties that might inhibit or prevent plant establishment or growth in the initial soil sample results, we did not conduct additional soil sampling prior to the beginning of the experiment.

A second set of soil samples was collected for nutrient analysis after 1 field season on 4-5 November 1995. Four, 0.5 liter soil cores were collected from each study plot. As in the initial sampling, the samples were composited and a pin flag was used to mark the sample location (to prevent repetitive sampling). Soil samples were allowed to air dry, then sent to Utah State University for analysis. All samples collected (32) were analyzed for $\mathrm{pH}$, electrical conductivity, phosphorus (Olson), potassium, texture, lime, and total nitrogen.

\section{Precipitation}

One rain gauge was placed at each dump location on 3 February 1995. Antifreeze and oil were added to the rain gauge to prevent freezing and evaporation of precipitation. Measurements were collected every month during the 1995 and 1996 field seasons. Data for the beginning of the 1995 water year were estimated from precipitation at the closest National Climate Data Center weather station (Tuscarora, Nev.) with a simple proportional correction.

\section{Statistical Analysis}

Analysis of Variance (ANOVA) with General Linear Models procedures (GLM) were used to examine all data sets (SAS Institute Inc. 1987). Assumptions of normality, additivity, and variance homogeneity for ANOVA were checked. The Shapiro-Wilk statistic for normality ( $\mathrm{P}<$ 0.1 ), normal probability plots, and stem leaf plots in the PROC UNIVARIATE procedure were used to determine if the data sets were normally distributed. Residual plots were used to examine the additivity and variance homogeneity of each data set. Data sets were checked for outliers by plotting standardized residuals against predicted values; no outliers were observed, therefore no observations were removed. When necessary, data were transformed to: 1 ) make error variances more homogenous; 2) improve additivity; and 3) improve normality. The Box and Cox test (Box and Cox 1964) was used to determine the appropriate power transformation.

In general, data sets with 1 or 2 measurement dates were initially analyzed using a split-strip-split plot model appropriate for the data set, whereas data with more than 2 measurement dates were analyzed as a repeated measures analysis. For all ANOVA's, $\mathrm{P} \leq 0.05$ was considered statistically significant. The most common treatment factors for each data set were: dump location at 2 levels (North Generator and Burns Basin); either soil type at 2 levels (mine waste and coversoil) or treatment type at 4 levels (untreated mine waste, fertilizer, coversoil, and fertil izer plus coversoil); location on the slope at 2 levels (upper and lower study plots); species at 6 levels (Bromus inermis, Elymus elymoides, Penstemon palmeri, Sanguisorba minor, Chrysothamnus nau seosus, and Purshia tridentata); and time at varying levels. The general split-stripsplit plot design was a split plot with respect to dump location, a strip plot with respect to treatment type and slope location, and a split-split plot with respect to species or time (Table 1). If dump and all dump interaction terms were not significant in the initial full model analysis, then the dump factor was removed from the model and the analysis was repeated on the simplified model (Table 1).

Three exceptions to this general pattern of statistical analyses occurred. First, insufficient computer memory was available to run a repeated measures analysis with all treatment factors for the transplant survival data set. Thus, time was removed from the initial analysis of the transplant survival data by averaging data over all sample dates. Data were then analyzed with a split-strip-split-split plot design. Because dump and all dump interaction terms were not significant in this ANOVA, dump was removed from the model, time was added back in, and transplant survival data were reanalyzed with a repeated measures analysis. Second, for seed density, measurements were collected at 4 locations on the slope rather than 2: in addition to the upper and lower study plots, the area between the upper and lower study plots and the area below the lower plot was sampled. Finally, plant nitrogen, transplant biomass, and water potential data sets had 3 levels of plant species (Elymus elymoides, Penstemon palmeri, and Chrysothamnus nauseosus) rather than 6.

To simplify presentation of the results, we have not included complete ANOVA tables. Instead, we only discuss those factors and interaction terms that were significant.

\section{Results}

\section{Seed Densities}

Very few seeds were present in the pretreatment seed bank. Five seeds of 2 genera used in our revegetation experiment, Bromus and Chrysothamnus, were recovered from 64 seed cores, which equates to an average of 0.5 and 2 seed $\mathrm{m}^{-2}$ for Bromus and Chrysothamnus, respectively. Unfortunately, identification of seeds to the species level was not possible because seeds of these 2 genera lack diagnostic characteristics. In addition, the pretreatment seed bank contained 1 or more seeds from the following taxa: Argumone muni ta, Astragalus spp., Carex nebrascensis, Chenopodium spp., Cirsium spp., Cryptantha gracilis, Marrubium vulgare,

Table 1. Summary of experimental design used for each type of data set. "N/A" indicates the treatment factor was not applicable to the data set; "N" indicates the number of treatment levels within a factor. “****”" indicates this main effect and all of its interaction terms were not significant; statistical model was then simplfied by the removal of this factor.

\begin{tabular}{|c|c|c|c|c|c|c|}
\hline Data Set & Factor A & Factor B & Factor $\mathrm{C}$ & Factor D & Factor E & Final ANOVA Model \\
\hline Seed Density & $* * * \operatorname{Dump}(\mathrm{N}=2)$ & Soil Type $(\mathrm{N}=2)$ & Slope Location $(\mathrm{N}=4)$ & Species $(\mathrm{N}=10 / 8)$ & Time $(\mathrm{N}=2)$ & Strip-split-split-split plot \\
\hline Seedling Density & Dump $(\mathrm{N}=2)$ & Main Plot Trt. $(\mathrm{N}=4)$ & Slope Location $(\mathrm{N}=2)$ & Time $(\mathrm{N}=10)$ & N/A & Repeated measures \\
\hline Transplant Survival & $* * * \operatorname{Dump}(\mathrm{N}=2)$ & Main Plot Trt. $(\mathrm{N}=4)$ & Slope Location $(\mathrm{N}=2)$ & Species $(\mathrm{N}=6)$ & Time $(\mathrm{N}=10)$ & Repeated measures \\
\hline Pre-Treatment Soil & $\operatorname{Dump}(\mathrm{N}=2)$ & Soil Type $(\mathrm{N}=2)$ & Slope Location $(\mathrm{N}=2)$ & N/A & N/A & Split-strip plot \\
\hline Post Treatment Soil & Dump $(\mathrm{N}=2)$ & Main Plot Trt. $(\mathrm{N}=4)$ & Slope Location $(\mathrm{N}=2)$ & $\mathrm{N} / \mathrm{A}$ & $\mathrm{N} / \mathrm{A}$ & Split-strip plot \\
\hline Plant Nitrogen & $* * * \operatorname{Dump}(\mathrm{N}=2)$ & Main Plot Trt. $(\mathrm{N}=4)$ & Slope Location $(\mathrm{N}=2)$ & Speices $(\mathrm{N}=3)$ & $\mathrm{N} / \mathrm{A}$ & Strip-split-split plot \\
\hline Transplant Biomass & $* * *$ Dump $(\mathrm{N}=2)$ & Main Plot Trt. $(\mathrm{N}=4)$ & Slope Location $(\mathrm{N}=2)$ & Species $(\mathrm{N}=3)$ & N/A & Strip-split-split plot \\
\hline Plant $\psi$ & Dump $(\mathrm{N}=2)$ & Main Plot Trt. $(\mathrm{N}=4)$ & Slope Location $(\mathrm{N}=2)$ & Time $(\mathrm{N}=3)$ & Time $(\mathrm{N}=4)$ & Repeated measures \\
\hline
\end{tabular}




\section{Mine Waste Coversoil}

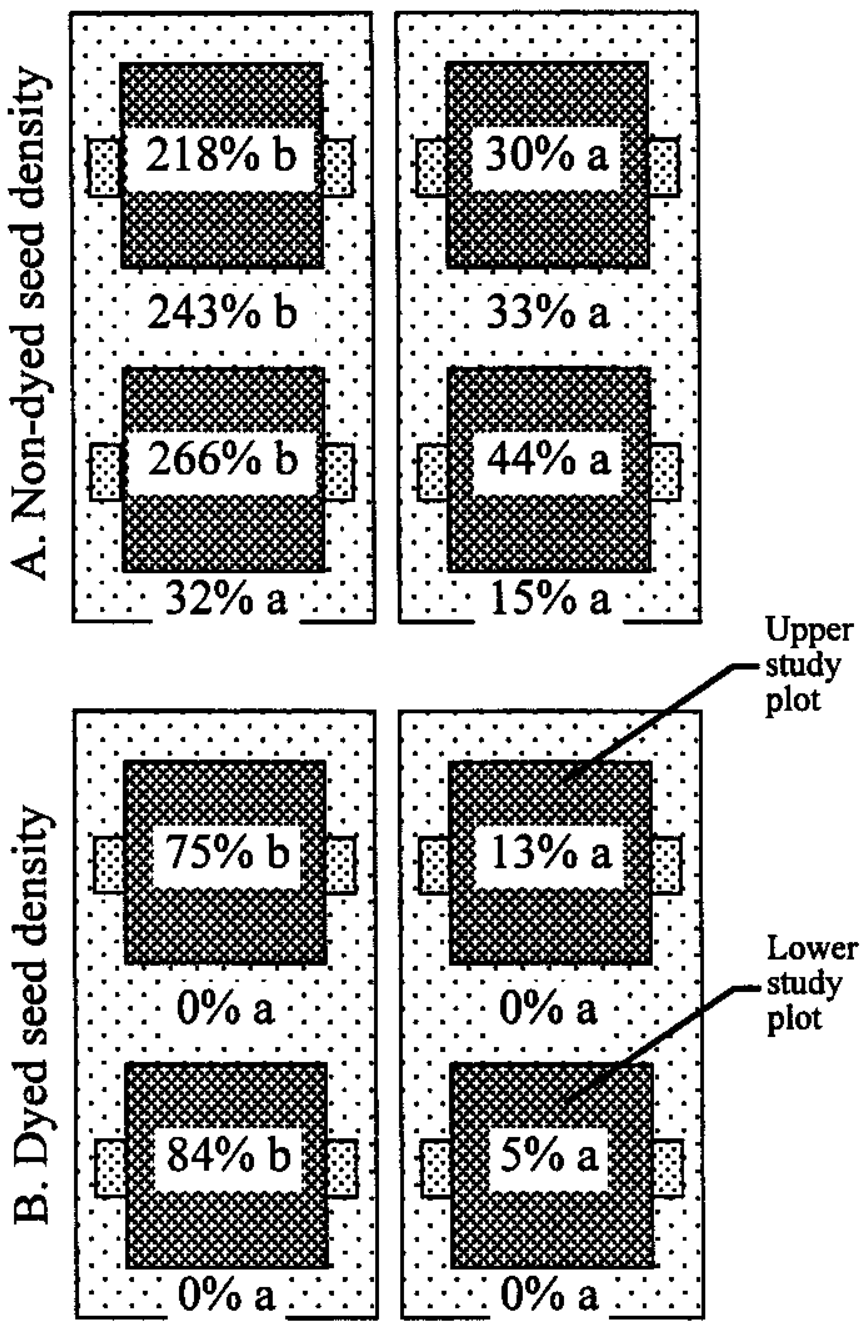

Fig. 2. Seed density, expressed as a percentage of the expected number of seeds, from soil cores collected 18 June and 4 Nov. 1995 for non-dyed $(A)$ and dyed $(B)$ seeds $(n=32)$. Mean values followed by the same letter within each graph were not significantly different.

Oxalis spp., Polygonum douglasii, Potentilla spp., and Viola spp. On average, the pretreatment seed bank contained a total of 35 seed $\mathrm{m}^{-2}$ over all species, compared to over $600 \mathrm{seed}^{-2}$ (includes live seeds, infertile seeds, and dyed seeds) that were broadcast. Because the pretreatment seed bank contained only 5 seeds that were in the same genus as those used in the study, pretreatment seed densities were not factored into the data analyses.

Non-dyed seed densities were significantly different among the 4 slope locations on untreated mine waste but not for coversoiled plots (Fig. 2A). However, the differences on mine waste were contrary to expectations if seeds preferentially move down slope: seed densities below the lower study plots were significantly lower than those for all other up-slope locations. These interpretations of the location effect were made cautiously because the location main effect $(\mathrm{P}<$ $0.001)$, the soil*location interaction $(\mathrm{P}=$ 0.012 ), and the species*location interaction $(\mathrm{P}<0.001)$ were all significant. For the species*location interaction, seed densities below the lower study plot were significantly lower than at least 1 up-slope location for 7 species but not significant for 3 species (Linum lewisii, Penstemon palmeri, and Artemisia tridentata). Thus, the location main effect and species*location interaction indicated that significant location differences occurred over both soil types, whereas the soil*location interaction indicated that the location differences were significant only on mine waste. Because seed densities were 6 times greater on mine waste in comparison with coversoil, we inferred that this greater seed density on mine waste skewed the significance of the main location effect. Thus, our interpretation of the location effect was based on the soil*location interaction.

Mine waste had significantly higher seed densities than coversoil for all slope locations except below the lower study plot. The soil main effect was significant $(\mathrm{P}=0.017)$, and mean comparisons (Fig. 2A) for the soil*location interaction indicate a significant difference between mine waste and growth medium soils for all but the lowest slope location. Mean comparisons for the soil*species interaction $(\mathrm{P}<$ 0.001 ) showed that mine waste had significantly higher seed densities than coversoil for all species except Linum lewisii, Penstemon palmeri, and Artemisia triden tata (data not shown). In addition, mean comparisons for the date main effect $(\mathrm{P}=$ $0.018)$ and soil*date interaction $(\mathrm{P}<$ $0.001)$ indicate that: 1) significantly greater numbers of non-dyed seeds were recovered on mine waste on both sample dates; and 2) seed recovery significantly decreased with time for mine waste but did not significantly change for coversoil.

Non-dyed seed density for Artemisia tridentata, Penstemon palmeri, and Linum lewisii were significantly lower than those for all other species (species main effect $\mathrm{P}<0.001)$. The species*location, species*treatment, and species*date $(\mathrm{P}=0.038)$ interactions indicated variations in species groupings within study plot location and main plot treatment (data not shown). For example, seed densities for Elymus elymoides, Bromus iner mis, Elymus hispidus, and Purshia triden tata prior to seed dispersal were significantly higher than densities after seed dispersal.

In general, results for the dyed seeds were similar to those for non-dyed seeds. For example, the recovery of dyed seeds from the upper and lower study plots was not significantly different within a particular soil type, but recovery from the upper and lower study plots was significantly greater than that between the plots and below the lower plot (Fig. 2B) only for the mine waste (location main effect $\mathrm{P}=$ 0.003; soil*location interaction $\mathrm{P}=0.003$ ). Second, densities of dyed seeds were significantly greater on mine waste than on coversoil for both the upper and lower slope locations (soil main effect $\mathrm{P}=$ 0.042). Finally, species differences for dyed seeds were also similar to those for non-dyed seeds (species main effect $\mathrm{P}<$ 0.001 ; species*location interaction $\mathrm{P}<$ $0.001)$. The most interesting results were that no dyed seeds were recovered in the 
plot areas located between the upper and lower study plots or below the lower study plots for either soil type (Fig. 2B). In addition, no seeds sown in the upper plots (dyed pink) were found in lower study plots nor were seeds sown in the lower study plots (dyed green) found in the upper study plots.

\section{Seedling Densities}

Seedling densities were significantly greater on both treatments with coversoil (i.e., coversoil and fertilizer plus coversoil treatments) than on plots with mine waste (i.e., untreated mine waste and fertilizer treatment). The treatment main effect was significant $(\mathrm{P}=0.050)$, and mean comparisons indicate significant differences between soil types but no significant differences between fertilizer treatments

Table 2. Mean comparisons of seedling density among main plot treatments $(n=80)$. Mean values followed by the same letter are not sig nificantly different $(P>\mathbf{0 . 0 5})$.

\begin{tabular}{lc}
\hline \hline Main Plot Treatment & Seedling Density \\
\hline Untreated Mine Waste & $\left(\right.$ plants $\mathrm{m}^{-2}$ ) \\
Fertilizer & $0.25 \mathrm{a}$ \\
Coversoil & $0.07 \mathrm{a}$ \\
Fertilizer \& Coversoil & $17.75 \mathrm{~b}$ \\
\hline
\end{tabular}

(Table 2). Mean comparisons for the dump*date interaction (Fig. 3A) indicate that seedling densities on the Burns Basin Dump generally were higher than those on the North Generator Dump, but this difference was significant on only 6 of the 10 sampling dates.

Although the location*date interaction was significant, seedling densities at different slope locations were only statistically different on 1 measurement date early in the second growing season (Fig. 3B). The upper study plot had significantly higher seedling densities than the lower study plot on 31 May 1996, which is contrary to expectations if seeds preferentially move down slope. The location effect and all other interaction terms with location were not significant in the analysis of variance.

\section{Transplant Survival}

Survival of transplants on both sets of coversoiled plots was significantly greater than that on both untreated and fertilized mine waste (Table 3 ). No significant differences occurred between fertilized and unfertilized plots within the same soil type. The significant treatment*date inter-

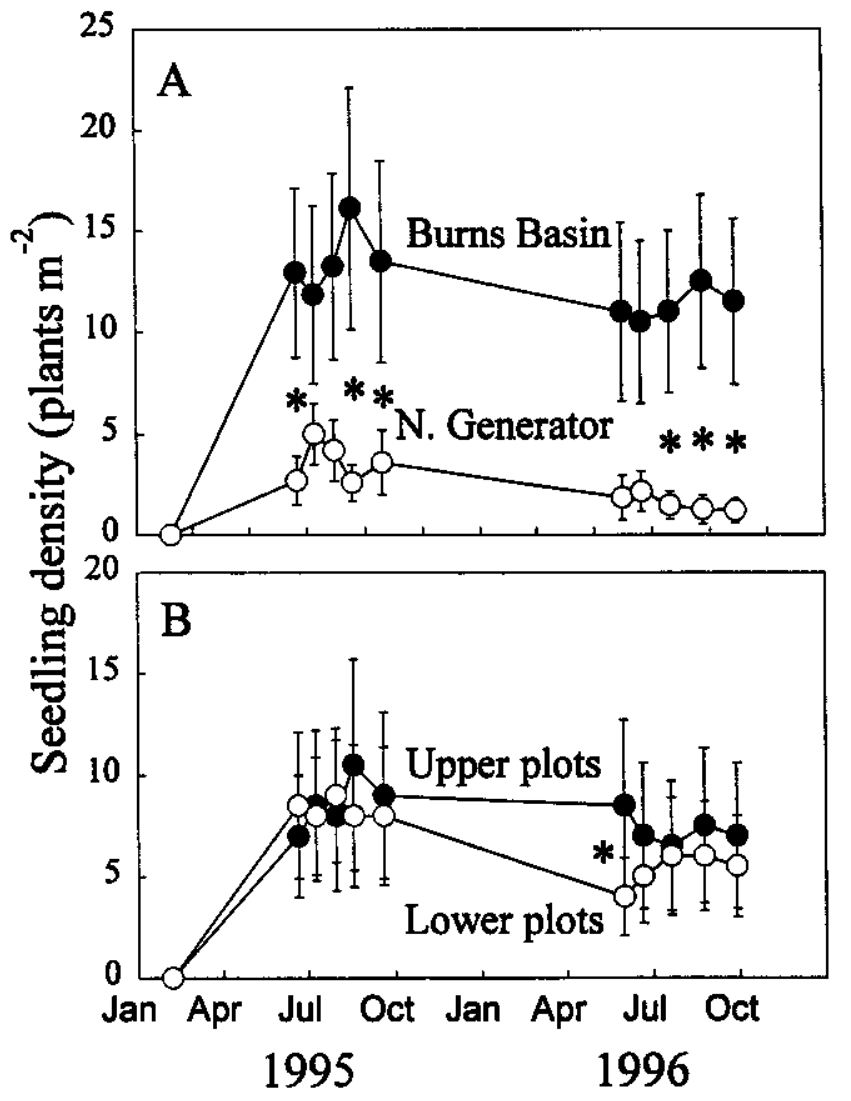

Fig. 3. Seedling density data. Asterisk indicates that means were significantly different on that particular sampling date. Error bars are standard error of the mean. A. Mean comparisons for the dump*date interaction $(P=0.018 ; n=16)$. B. Mean comparisons for the location*date interaction $(P=0.025 ; n=16)$.

action $(\mathrm{P}<0.001)$ supported the treatment main effect results stated above. From 19 August 1995 until 28 September 1996, transplant survival was significantly higher for coversoiled plots, and no significant differences occurred between fertilizer treatments within the same soil type on any sampling date (Fig. 4). For example, even though transplant survival on untreated mine waste consistently ranked higher than survival on fertilized plots, survival rates on untreated and fertilized plots were not statistically different on any sampling date.

Table 3. Mean comparisons of transplant survivorship among main plot treatments (treatment main effect $P=0.005 ; n=480$ ). Mean values followed by the same letter are not significantly different $(P>0.05)$.

\begin{tabular}{lc}
\hline \hline Main Plot Treatment & Survivorship \\
\hline & $(\%)$ \\
Untreated Mine Waste & $59 \% \mathrm{a}$ \\
Fertilizer & $43 \% \mathrm{a}$ \\
Coversoil & $82 \% \mathrm{~b}$ \\
Fertilizer \& Coversoil & $86 \% \mathrm{~b}$ \\
\hline
\end{tabular}

However, by the beginning of the fourth growing season (24 May 1998), survival rate decreased greatly for the coversoil treatments, and survival rates were not significantly different among treatments (Fig. 4). Although the treatment*location*date interaction was also significant $(\mathrm{P}=$ 0.023 ), differences among treatments at 1 slope location within any sample date were generally similar to those indicated by the treatment*date interaction. The exception was for the upper study plots; the difference in survival rates between the coversoil and mine waste treatment was not significant on any measurement date (data not shown).

Treatment effects did vary somewhat among species, as suggested by the significant treatment*species interaction $(\mathrm{P}<$ 0.001). For all species except Penstemon palmeri and Chrysothamnus nauseosus, transplant survival on mine waste (untreated and fertilizer treatment) was significantly lower than that on coversoils (data not shown). However, as with the treatment main effect and treatment*date interaction, transplant survival on the coversoil 


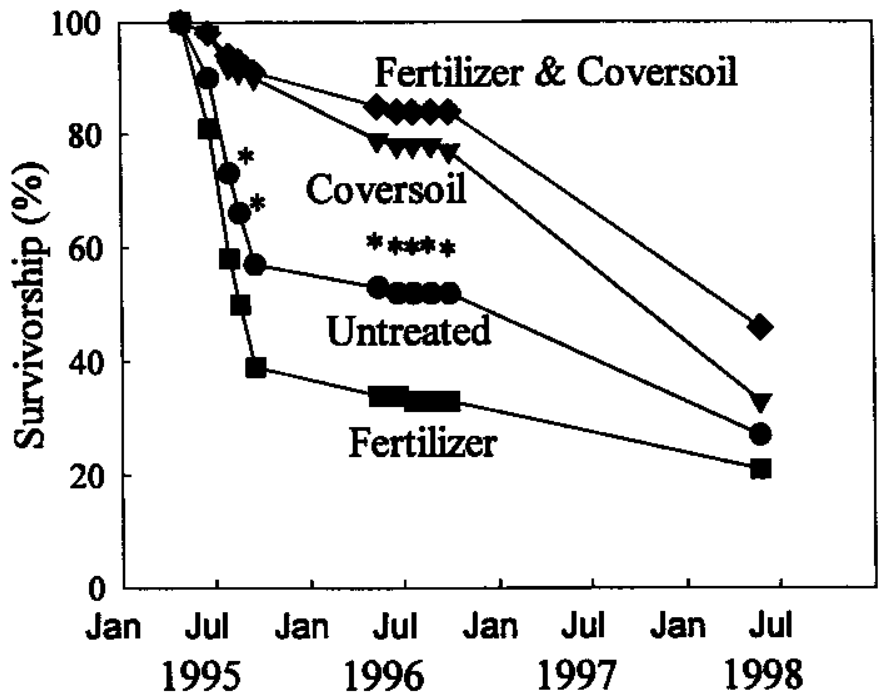

Fig. 4. Transplant survivorship data $(n=48)$. Treatments above the asterisk were significantly different from those below the asterisk on that particular sampling date. The treatments above or below the asterisk were not significantly different from each other. For dates without an asterisk, treatments were not significantly different.

and fertilizer plus coversoil treatments was not statistically different within any 1 species except for Chrysothamnus nauseo sus. Similarly, the effect of fertilization on transplant survival rates for plots with mine waste soil was not significant for all species except Bromus inermis and Penstemon palmeri.

Transplant survival varied significantly among species, but species differences within any treatment were generally not significant. The species main effect $(\mathrm{P}=$ 0.023 ) indicated that survival of Bromus inermis, Penstemon palmeri, and Sanguisorba minor was significantly less than that of other species (data not shown). However, mean comparisons for the treatment*species interaction indicate that differences among species varied within treatment type (data not shown). Transplant survival was highest for Penstemon palmeri on untreated mine waste, for Elymus elymoides on fertilized plots, and for Purshia tridentata on both coversoil

Table 4. ANOVA $P$ values for the soil main effect and mean comparisons of soil properties prior to the application of fertilizer $(n=8)$. Mean values followed by the same letter within a row are not significantly different $(P>0.05)$.

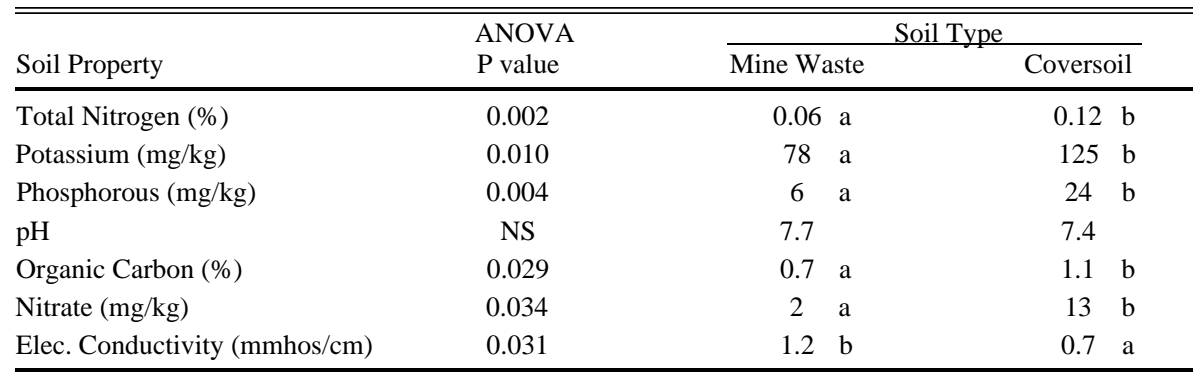

centage of coarse fragments $(>2 \mathrm{~mm})$ in mine waste soils $(69 \%)$ was significantly higher than that in growth medium soils $(51 \%)$. Soil texture for both soil types varied greatly within each study plot and ranged between silt loam, silty clay loam, clay loam, loam, and sandy clay loam.

The dump*soil interaction was only significant for potassium $(\mathrm{P}=0.024)$ and phosphorus $(\mathrm{P}=0.027)$. Mean comparisons for potassium indicated that differences between mine waste and coversoil were significant for Burns Basin Dump but not for North Generator Dump (data not shown). For phosphorus, differences between mine waste and coversoil were significant at both dumps. The dump*soil interaction also indicated differences in potassium and phosphorus between dumps for coversoil but not for mine waste. Coversoil on the Burns Basin Dump had significantly greater potassium levels than that on the North Generator Dump, but significantly less phosphorus.

The dump*location interaction was only significant for nitrate $(P=0.021)$. Mean comparisons indicate that the upper study plots at the North Generator Dump (13 mg $\mathrm{kg}^{-1}$ ) contained significantly greater amounts of nitrate than those at the Burns Basin Dump (4 $\mathrm{mg} \mathrm{kg}^{-1}$ ). However, nitrate levels in the lower study plots at the North Generator Dump $\left(9 \mathrm{mg} \mathrm{kg}^{-1}\right)$ and Burns Basin Dump (4 mg kg-1) were not significantly different. In addition, nitrate levels among upper and lower study plots were not significantly different within each dump.

Although significant differences among treatments for total nitrogen, phosphorus, potassium, and $\mathrm{pH}$ occurred 1 year after treatment (Table 5), these differences were related to soil type differences (i.e. mine waste versus coversoil), as opposed to fertilizer differences, for all soil factors except phosphorus. As occurred prior to fertilization, both coversoil treatments contained significantly higher amounts of total nitrogen, phosphorus, and potassium than both untreated and fertilized mine waste (Table 5). The reverse occurred for $\mathrm{pH}$ : mine waste had significantly higher $\mathrm{pH}$ values than coversoil. Differences due to the application of fertilizer were only detectable for phosphorus. Fertilized plots contained significantly higher amounts of phosphorus than untreated mine waste, and fertilizer plus coversoil had significantly higher phosphorus levels than coversoil (Table 5).

The dump main effect $(\mathrm{P}=0.039)$ and the dump*treatment interaction $(\mathrm{P}=$ $0.037)$ were significant only for phosphorus. Over all treatments, North Generator 
Table 5. ANOVA $P$ values for the treatment main effect and mean comparisons of soil properties one year after fertilization $(n=8)$. Mean values followed by the same letter within a row are not significantly different $(P>0.05)$.

\begin{tabular}{|c|c|c|c|c|c|}
\hline \multirow[b]{2}{*}{ Soil Property } & \multirow[b]{2}{*}{$\begin{array}{r}\text { ANOVA } \\
\text { P value }\end{array}$} & \multicolumn{4}{|c|}{ Main Plot Treatment } \\
\hline & & $\begin{array}{c}\text { Untreated } \\
\text { Mine Waste }\end{array}$ & Fertilizer & Coversoil & $\begin{array}{c}\text { Fertilizer \& } \\
\text { Coversoil }\end{array}$ \\
\hline Total Nitrogen $(\%)$ & $<0.001$ & 0.06 a & $0.06 \mathrm{a}$ & $0.14 \mathrm{~b}$ & $0.12 \mathrm{~b}$ \\
\hline Potassium (mg/kg) & 0.007 & 56 & $72 \mathrm{a}$ & $123 \mathrm{~b}$ & $128 \mathrm{~b}$ \\
\hline Phosphorus (mg/kg) & $<0.001$ & $\mathrm{a}$ & $10 \mathrm{~b}$ & $19 \mathrm{c}$ & $24 \mathrm{~d}$ \\
\hline $\mathrm{pH}$ & 0.001 & $7.7 \quad b$ & $7.7 \mathrm{~b}$ & $7.1 \mathrm{a}$ & $7.1 \mathrm{a}$ \\
\hline E. C. $(\mathrm{mmhos} / \mathrm{cm})$ & NS & 1.0 & 1.0 & 1.7 & 2.2 \\
\hline
\end{tabular}

Dump plots treated with coversoil or fertilizer plus coversoil contained significantly higher amounts of phosphorus than untreated and fertilized mine waste on the North Generator Dump as well as all treat ments at the Burns Basin Dump. However, treatment effects within dump were generaly similar to the main treatment effect: coversoil contained greater amounts of phosphorus than mine waste within each dump, and a fertilizer effect on soil phosphorus occurred between the untreated and fertilizer treatments (data not shown).

\section{Plant Nitrogen Content and Biomass}

Nitrogen content-Differences in plant aboveground nitrogen pools among treatments (treatment main effect $\mathrm{P}=0.030$ ) reflected soil type differences. Plants on coversoil with or without fertilizer contained significantly higher nitrogen pool sizes than plants on both mine waste treat-

Table 6. Mean comparisons of transplant above ground plant nitrogen pools among main plot treatments $(n=24)$. Mean values followed by the same letter are not significantly different $(\mathrm{P}>0.05)$.

\begin{tabular}{lc}
\hline \hline Main Plot Treatment & $\begin{array}{c}\text { Above Ground Plant } \\
\text { Nitrogen Pools }\end{array}$ \\
\hline & $(\mathrm{g})$ \\
Untreated Mine Waste & $2.8 \mathrm{a}$ \\
Fertilizer & $2.9 \mathrm{a}$ \\
Coversoil & $9.3 \mathrm{~b}$ \\
Fertilizer \& Coversoil & $6.9 \mathrm{~b}$ \\
\hline
\end{tabular}

ments (Table 6). Nitrogen pool sizes of plants on fertilized and unfertilized plots with the same soil type were not significantly different. Mean comparisons for the treatment* species interaction $(\mathrm{P}=0.008)$ indicated similar results as the main treatment effect: greater plant nitrogen pool size for plants on both coversoil treat- ments, but differences were significant only for Elymus elymoides. As observed with the treatment main effect, significant differences between unfertilized and fertilizer treatments did not occur within any 1 species (data not shown).

Both plant aboveground nitrogen pools and tissue nitrogen content varied significantly among species (species main effect $\mathrm{P}<0.001$ for both variables), with Penstemon palmeri having the lowest nitrogen values (data not shown). The species*treatment interaction was only significant for the plant aboveground nitrogen pool size. Species ranking was consistent with the main treatment effect: Chrysothamnus nauseosus had the highest nitrogen pools and Penstemon palmeri had the lowest for all treatment types except coversoil. For the coversoil treatment, Elymus elymoides contained the highest nitrogen pools and Chrysothamnus nau seosus the lowest. However, the statistical grouping of species within treatment type varied.

Biomass_Plant biomass in June 1995 did not differ among treatments. None of the factors or interactions in the strip-splitsplit analysis of variance were significant.

Canopy volume at the beginning of the fourth growing season was significantly different among treatments for only 1 species (species main effect $\mathrm{P}<0.001$; treatment*species interaction $\mathrm{P}<0.001$; treatment*location*species interaction $\mathrm{P}=$ 0.003). Chrysothamnus nauseosus on coversoil was significantly larger than that on

Table 7. Mean comparisons of transplant canopy volume, measured at the beginning of the fourth growing season 2 after transplanting, among main plot treatments for each species $(n=8)$. Mean values followed by the same letter within the table are not significantly different $(P>0.05)$.

\begin{tabular}{lcccc}
\hline \hline Species & $\begin{array}{c}\text { Untreated } \\
\text { Mine Waste }\end{array}$ & Fertilizer & Coversoil & $\begin{array}{c}\text { Fertilizer \& } \\
\text { Coversoil }\end{array}$ \\
\hline Elymus elymoides & $0.1 \mathrm{a}$ & $<0.1 \mathrm{a}$ & $0.8 \mathrm{a}$ & $1.3 \mathrm{a}$ \\
Penstemon palmeri & $12 \mathrm{a}$ & $6 \mathrm{a}$ & $188 \mathrm{a}$ & $108 \mathrm{a}$ \\
Chrysothamnus nauseosus & $24 \mathrm{a}$ & $13 \mathrm{a}$ & $2,066 \mathrm{~b}$ & $2,559 \mathrm{~b}$ \\
\hline
\end{tabular}

mine waste (Table 7). Mean comparisons among treatments for Elymus elymoides and Penstemon palmeri indicated that plant sizes were always higher for coversoil than for mine waste, but these differences were not statistically significant. Significant differences between unfertilized and fertilizer treatments did not occur for any species (Table 7).

\section{Water Potential}

Long-term (35 yr.) average annual precipitation at the closest National Climate Data Center official weather station, Tuscarora, Nev. $\left(41^{\circ} 19^{\prime} \mathrm{N} 116^{\circ} 13^{\prime} \mathrm{W}\right.$, $1,881 \mathrm{~m})$, is $33 \mathrm{~cm}$. Precipitation at Tuscarora for the period 1 October 1994 to 30 September 1995 was $6.5 \mathrm{~cm}$ above the long-term average and for the period 1 October 1995 to 30 September 1996 was $3.4 \mathrm{~cm}$ above the long-term average. Precipitation at the study plots averaged $73 \mathrm{~cm}$ and $51 \mathrm{~cm}$ during the 1995 and 1996 water years, respectively (data not shown). The majority of the precipitation was from snow received in the winter and early spring.

Differences in predawn plant water potential among treatments reflected soil type rather than fertilizer treatment at the Burns Basin Dump (Table 8). Mean comparisons for the dump*treatment interaction $(P=0.031)$ indicated that water potential of plants on plots that received the coversoil or fertilizer plus coversoil treatments was significantly greater than that on untreated mine waste or fertilizer treatments at Burns Basin Dump. Predawn plant water potential was not significantly different among treatments at the North Generator Dump.

Predawn water potential for plants located on the North Generator Dump was generally lower than that on the Burns Basin Dump. However, the difference was only statistically significant for the coversoils (Table 8). Furthermore, the dump*species*date interaction $(\mathrm{P}=0.037)$ indicated that differences between dumps occurred on all dates for Penstemon palmeri, on all measurement dates except 1 for Elymus elvmoides, on none of the dates for Chrysothamnus nau seosus. 
Table 8. Mean comparisons of predawn plant water potential (w) among main plot treatments and dump $(n=48)$. Mean values followed by the same letter within the table are not significantly different $(\mathrm{P}>0.05)$.

\begin{tabular}{lcccc}
\hline \hline Site & Mine Waste & Fertilizer & Coversoil & Fertilizer \& Coversoil \\
\hline & $(\mathrm{MPa})$ & $(\mathrm{MPa})$ & $(\mathrm{MPa})$ & $(\mathrm{MPa})$ \\
Burns Basin Dump & $-0.86 \mathrm{~b}$ & $-0.84 \mathrm{~b}$ & $-0.53 \mathrm{a}$ & $-0.46 \mathrm{a}$ \\
North Generator Dump & $-0.85 \mathrm{~b}$ & $-0.97 \mathrm{~b}$ & $-0.81 \mathrm{~b}$ & $-1.25 \mathrm{~b}$ \\
\hline
\end{tabular}

Predawn plant water potential values varied significantly among species (species main effect $\mathrm{P}=0.005)$, with Chrysothamnus nauseosus (mean over all dates $=-0.88 \mathrm{MPa}$ ) having the most negative values and Penstemon palmeri $(-0.78$ $\mathrm{MPa})$ the least. The difference between Chrysothamnus nauseosus and Penstemon palmeri was significant, but no significant differences occurred between Elymus ely moides $(-0.85 \mathrm{MPa})$ and Chrysothamnus nauseosus or between Elymus elymoides and Penstemon palmeri. Mean comparisons for the species*date interaction $(\mathrm{P}<$ $0.001)$ indicated that differences among species were primarily due to large differences among species early in the growing season (data not shown).

Mid-day plant water potential values varied significantly among species within the first 2 measurement dates ( species*date interaction $\mathrm{P}=0.004)$. Water potential for Chrysothamnus nau seosus was significantly lower than that for Elymus elymoides on the first measurement date, but differences between Penstemon palmeri and Chrysothamnus nauseosus were not significant (data not shown). On the second measurement date, Penstemon palmeri was significantly lower than Elymus elymoides, but differences in plant water potential between Chrysothamnus nauseosus and the other 2 species were not significant on the second measurement date. Mid-day plant water potential values among species were not significantly different on the last 2 measurement dates.

\section{Discussion}

This study examined 4 mechanisms that may influence revegetation of angle of repose slopes: 1) long distance movement of seeds along the slope face; 2) effects of coversoil on seedling establishment: 3 ) effects of fertilization on plant establishment; and 4) gradients of plant water status along angle of repose slopes. Physical forces such as wind and slope characteristics interact with seed and soil surface characteristics to determine seed dispersal distance and direction (Johnson and Fryer 1992, Matlack 1989, Watkinson 1978, Westelaken and Maun 1984). For example, gravity can move seeds downslope in steep terrain. However, the results from our study indicate that long distance, downslope movement of seeds was not significant on stable slopes over the February to November time period. If seeds had been transported down slope by wind, water, or gravity, a seed gradient would have existed with fewer seeds at the upper study plots and more at the lower study plots. In addition, if seeds were moving down slope. fewer seedlings would have been present on the upper plots, provided the conditions necessary for seedling establishment were adequate. The only seed gradient detected in this study (Fig. 2A) was contrary to expectations: the area located below the lower study plot on mine waste had significantly fewer non-dyed seeds than all other up slope locations. Furthermore, no dyed seeds sown in the upper plots (dyed pink) or seeds sown in the lower plots (dyed green) were found outside of the plots in which the seeds were sown. However, note that our seed bank sampling was restricted to areas outside of erosion rills and areas of mass soil movement. With erosion and mass wastage, seeds would, of course, move long distances downslope, but seeds initially near the soil surface would likely be buried too deeply by eroding sediments for seedling emergence.

The presence of fine soil materials from coversoiling facilitated seedling emergence (Table 2) and enhanced transplant survival (Table 3 ), as has been noted in many previous studies (e.g. DePuit and Redente 1988, Ferris et al. 1997, Harris et al. 1996, Munshower 1994). We expected greater seedling densities on coversoil if its fine texture facilitated soil-seed contact and provided the necessary conditions for seed germination and seedling establishment. Likewise we expected higher transplant survival rates on coversoil if the fine texture enhanced soil-root contact and provided the necessary conditions for survival. In contrast, few seedlings emerged on mine waste, even when fertilized. Clearly, seed transport and fate did not greatly influence seedling distribution patterns on mine waste. On coarse textured mine waste soil, an adequate seed bank was present (Fig. 2A), yet very few seedlings emerged on these sites (Table 2). The presence of seeds along with the absence of seedlings indicates that some mechanism other than seed transport is responsible for limiting seedling establishment on mine waste. Because approximately $50 \%$ of the transplants on mine waste were able to survive during the first 2 years, mine waste soil is adequate to provide soil-root contact and water and nutrients are in sufficient quantities to sustain the growth of mature plants. Thus, low seedling densities on mine waste indicate the absence of microsite conditions that favor seed germination and seedling establishment. Although soil-seed contact was probably 1 of the inadequate microsite conditions that limited seed germination on mine waste, the data set from this study did not quantify soil-seed contact or other conditions such as soil moisture and temperature that influence seed germination and seedling emergence and survival.

Although fine textured coversoil was more susceptible to erosion and mass movement, there was no indication that soil movement was responsible for shearing roots from their shoots. If shearing occurred, seedlings would have been expected to emerge but not survive on coversoil treatments whereas transplants would have survived. Seedlings emerged and survived on coversoil (Fig. 4). Thus, shearing did not inhibit seedling survival on coversoil.

Nutrient availability did not appear to limit seedling or transplant survival on angle of repose slopes. If soil nutrients had not been available in sufficient quantities to sustain plant survival, then we expected greater seedling density and transplant survival through time on fertilized plots. However, no statistical differences in seedling density or transplant survival rates occurred between unfertilized and fertilized plots (Tables 2, 3). Results from soil analysis of mine waste also indicated that soil nutrients were present in sufficient quantities to support plant growth (Table 4). Thirdly, downslope movement of soil nutrients was not detected. If nutrients were transported downslope, then we expected a nutrient gradient with low nutrient levels at the upper study plots and high nutrient levels at the lower study plots. However, no statistical differences between upper and lower study plots occurred for soil nutrients or for plant aboveground nitrogen values. 
Plant water potential data indicated no treatment or location differences. If the presence of fine textured soils had increased water-holding capacity, then we expected plants on coversoil to be less water stressed than plants on mine waste. In addition, if water had preferentially accumulated downslope, then we expected plants in the lower study plots to be less water stressed than plants in upper plots. Neither of these expectations were supported by our results.

When all our results are considered in total, inadequate microsite conditions for seed germination and seedling establishment on mine waste was the primary factor that inhibited plant establishment on angle of repose slopes. Although coversoiling increased both seedling emergence and transplant survival, coversoiled angle of repose slopes were more susceptible to soil erosion and mass soil movement. Soil loss was not measured in the experiment, but erosion rills and mass soil movement were visually more common on coversoil than on mine waste. In addition, transplant survival on coversoil dropped from $80 \%$ to $40 \%$ during the third growing season, and soil type differences were no longer significant. Thus, long-term revegetation success and the risk of mass soil wastage (with subsequent sediment load into the watershed) need to be carefully considered when coversoiling angle of repose slopes to revegetate from seeds.

Transplanting container-grown plants onto mine waste is an alternative to seeding that does not require coversoiling angle of repose slopes. Our results indicate that water, nutrients, and soil characteristics of mine waste were sufficient to sustain growth of container-grown plants and at least some transplants survived on mine waste through 4 growing seasons. However, survival rates and plant biomass of container-grown stock on mine waste were significantly lower than those on coversoil during much of the study period. Thus, the expense to transplant containerized stock directly onto angle of repose mine waste has to be carefully considered given the lowered potential for long term establishment of vegetation.

The results of this study indicate that although the coarse textured soils on angle of repose slopes provide for slope stability, they also limit revegetation by inhibiting seed germination and seedling establishment. In contrast, highly erosive, fine textured coversoils may enhance plant establishment and survival during the short term, but unstable slopes eventually lead to plant mortality. To ensure the highest revegetation success, an alternative method is needed that provides both good soil-seed contact and long-term soil stability. For example, hydro-seeding and hydromulching have been successful on angle of repose slopes (Golder 1994), but long-term slope stabilization has not been adequately established with these techniques.

\section{Literature Cited}

Archibold, O.W. 1980. Seed input as a factor in the regeneration of strip-mine wastes in Saskatchewan. Can. J. Bot. 58:1490-1495.

Box, G.E.P. and D.R. Cox. 1964. An analysis of transformation. J. Royal Stat. Soc. Ser. B. 26:211-243.

Chambers, J.C. 1995. Relationships between seed fates and seedling establishment in an alpine ecosystem. Ecol. 76:2124-2133.

Chambers, J.C. and J.A. MacMahon. 1994. A day in the life of a seed: movements and fates of seeds and their implications for natural and managed systems. Ann. Rev. Ecol. Syst. 25:263-292.

DePuit, E.J. and E. F. Redente. 1988 . Manipulation of ecosystem dynamics on reconstructed semiarid lands. p. 162-204. In: EB. Allen (ed.), The reconstruction of disturbed arid lands: an ecological approach. AAAS Selected Symp. 109, Westview Press, Boulder, Colo.

Ferns, F.K., LH. Kleinman, B.C. Postovit, D.G. Steward, KR. Stowe, and LE. Vicklund. 1997. Handbook of western reclamation techniques. USDI Office of Technology Transfer, Western Regional Coordinating Center, Office of Surface Mining, Denver, Colo.

Golder Associates Inc. 1994. Technical memorandum: steep slope reclamation Gold Bar Mine, Nevada. Golder Associates Inc., Lakewood, Colo.

Gray, D.H. and A.T. Leiser. 1982. Biotechnical slope protection and erosion control. Van Nostrand Reinhold Company, New York, N.Y.

Harris, J.A., P. Birch, and J. Palmer. 1996. Land restoration and reclamation: principles and practices. Addison Wesley Longman, Ltd., Harlow, Essex, England.

Holbrook, N.M., M.J. Burns, and C.B. Field. 1995. Negative xylem pressures in plants: A test of the balancing pressure technique. Sci. 270:1193-1194.

Johnson, E.A. and G.L Fryer. 1992. Physical characteristics of seed microsites-movement on the ground. J. Ecol. 80:23-836.

Keeley, H.C.M. 1978. The cost-cffectiveness of certain methods of recovering macroscopic organic remains from archaeological deposits. J. Arch. Sci. 5:179-183.

Matlack, G.R. 1989. Secondary dispersal of seed across snow in Betula lenta, a gap-colonizing tree species. J. Ecol. 77:853-869.
Meyer, S.E. and S.B. Monsen. 1989. Seed germination biology of antelope bitterbrush (Purshia tridentata). p. 147-157 In: A. Wallace, E.D. McArthur, and M.R Haferkamp (compilers), Shrub ecophysiology and biotechnology. Proceedings from a symposium. Gen. Tech. Rep. INT-256, USDA Forest Serv. Intermountain Res. Sta., Ogden, Utah.

Molyneux, J.K. 1962. Colliery waste heaps. J. Ecol. 51:315-321.

Munshower, F.F. 1994. Practical handbook of distuibed land revegetation. Lewis Publishers CRC Press, Boca Raton, Fla.

Russell, W.B. 1985. Natural vegetation and ecology of abandoned coal-mined land at Sterco-Coal Valley, Rocky Mountain Foothills, Alberta. Pages 145-162 In: P.F. Ziemkiewicz (ed.), Revegetation methods for Alberta's mountains and foothills, proceedings of a workshop. Alberta Land Conserv. Reclam. Counc. Rep. \#RRTAC 85-1, Edmonton, Alberta.

SAS Institute Inc. 1987. SAS/STAT guide for personal computers, version 6. SAS Institute Inc., Cary, N.C.

Turner, N.C. and M.J. Long. 1980. Errors arising from rapid water loss in the measurement of leaf water potential by the pressure chamber technique. Aust. J. Plant Physiol. 7:527-537.

Waring, RH. and B.D. Cleary. 1967. Plant moisture stress: evaluation by pressure bomb. Sci. 155:1248-1254.

Watkinson, A.R. 1978. The demography of a sand dune annual: Vulpia fasciculata. III. The dispersal of seeds. J. Ecol. 66:483-498.

Westelaken, LL, and M.A. Maun. 1984. Spatial pattern and seed dispersal of Lithospermum caroliniense on Lake Huron sand dunes. Can. J. Bot. 63:125-132.

Young, J.A. and C. Ross. 1993. Revegetation in mine reclamation in Nevada. USDI Bureau of Land Manage. 71 pp. 